\title{
Towards the Implementation of Social Forestry Policy in Aceh Province, Indonesia: Process and Institutional Assessment
}

\author{
Silfi Iriyani ${ }^{1 *}$, A. Humam Hamid ${ }^{1}$, Agus Setyarso ${ }^{2}$ and Hairul Basri ${ }^{1}$ \\ ${ }^{1}$ Doctoral Program of Agricultural Sciences, Universitas Syiah Kuala, Banda Aceh, Indonesia \\ ${ }^{2}$ Fakultas Kehutanan, Universitas Gajah Mada, Kabupaten Sleman, Daerah Istimewa Yogyakarta, Indonesia
}

\begin{abstract}
The Indonesian government devised numerous strategic plans to achieve 12.7 million hectares of social forestry areas as targeted by the social forestry program. This target is achieved through specific policies issued by the Indonesian government, which regulate the implementation and management of village forests. This study examined the readiness of the Forest Management Unit and the Village Forest Management Institute as the main institutions involved in the implementation of village forests. Additionally, the study discovered that readiness was directly proportional to the poverty alleviation level among forest users, the improvement of forest conditions, and the empowerment of forest users. This research applied an objective-based evaluation and institutional assessment. Furthermore, the data obtained was qualitative data, which was quantified using a scale, then the calculated scale results were analysed to produce index value. The data analysis was employed by adopting an

ARTICLE INFO

Article history:

Received: 30 January 2020

Accepted: 24 August 2020

Published: 25 December 2020

DOI: https://doi.org/10.47836/pjssh.28.4.11

E-mail addresses:

iriyani.silf@gmail.com (Silfi Iriyani)

humamhamid@yahoo.com (A. Humam Hamid)

agusse@yahoo.com (Agus Setyarso)

hairulbasri@unsyiah.ac.id (Hairul Basri)

*Corresponding author

FMU performance appraisal method, which utilised community-managed forest management indicators. In the last five years, from the submission of the permit proposal to the issuance of forest license, the results showed an increase of community participation, particularly on the initiatives of (i) institutionalising business unit management, (ii) integration of the village forest management to the village fund, (iii) building the capacity of village enterprise
\end{abstract}

ISSN: 0128-7702

e-ISSN: 2231-8534 
group, and (iv) contributing to wildlife conflict mitigation.

Keywords: Forest management unit, policies, social forestry, village forest

\section{INTRODUCTION}

One of the means to manage forests is through community forestry or social forestry (SF), which integrates local practices and supports local livelihoods. The need to manage forests arises when there is concern over the high rate of deforestation. Thus, the government's responsibility is to control the preservation of forest resources and perform their capacity for forest protection and management (Moeliono et al., 2017). For the past few decades, SF was introduced by policymakers and subsequently became a top priority in government strategies (Fisher et al., 2018; Gauld, 2000) in their effort to overcome forest degradation and to reduce poverty (Khalyani et al., 2014; Ministry of Forest and Soil Conservation, 2013). These efforts were executed by mobilising community participation in managing the forests to further increase support from external parties and encourage community participation (Aju et al., 2019; Resosudarmo et al., 2019).

In Indonesia, SF is a policy that was recently reinvented in 2016. Village forest is one of the policy's program schemes implemented to improve welfare and reduce poverty (Santika et al., 2019) by legally empowering the social community so that they can manage and protect forests (Hutauruk et al., 2018). Besides, forest users were able to control the diversification of forest products to generate financial benefits (Yemiru et al., 2010). Therefore, the Indonesian government had specially elected a minister of environment and produced a forestry regulation program, which included the village forest scheme regulation. The target of the program was to establish 12.7 million hectares of SF areas by the end of 2019 (Resosudarmo et al., 2019; Tacconi \& Muttaqin, 2019) and aimed to diminish poverty, unemployment, and inequality in the management or utilisation of forest areas.

The SF implementation coincided with another new policy on establishing permanent forest management units (FMU). FMU is the area manager, whereas SF units hold utilisation licenses in the area. Hence, $\mathrm{SF}$ is required to be aligned in the framework of FMU. In short, two organisations are employed in the working area under FMU management.

This research examined the implementation and evaluation of SF under the parallel developing organisation of FMU in the Aceh Province. The study area focused on Aceh Province because the village forests in that area had been established since 2014, which was right after the establishment of FMU. Also, the five-year evaluation was linked to the government's commitment to improve land access for rural people and to provide opportunities for economic development, meanwhile protecting the remaining fragile forests, as discussed in the Indonesia Presidential Election Debate 2019 (Fisher et al., 2019). The implementation of 
SF is examined and required to be reported to the government and the public being one of the stakeholders.

According to the Indonesian Government Regulation Number 11 Year 2006, Aceh Province holds special autonomy in managing and utilising its natural resources, which include forest resources to improve society's quality of life. With that, Aceh Province can alter national policy and adjust it based on the local situation and dynamics. Thus, it has become a particular interest to analyse the policy implementation efficacy.

The basic approach adopted by this Article was two-fold (i) Theory of Organisation Readiness for Change, and (ii) Bottom-up Policy Implementation Assessment. Furthermore, the methods applied to employ these approaches are (i) Objective-based Evaluation (Maryudi et al., 2012) and (ii) Process-based mapping analysis (National Academies of Sciences, Engineering, and Medicine, 2011).

Past research studies have conducted an assessment of SF in Indonesia. Previously, Bong et al. (2019) discovered the analytical framework applied to determine the similarity and differences of a successful SF pattern. Through the use of this framework, the outcomes that enabled and hindered the implementation were discovered. Moreover, the challenge of SF implementation laid in the involvement of related institutions, which resulted in a conflict of interest that influenced the SF outcomes (Fisher et al., 2018).
Unfortunately, most case studies discussed SF only from a social and economic perspective (Rakatama \& Pandit, 2020) but not from an institutional perspective. Nevertheless, previous research by Tajuddin et al. (2019) stated that there were conflicts of interest between the SF program and FMU. The conflict resulted in difficulty in achieving the village forest objectives (Dash \& Behera, 2015), which showed that the issues related to institutional performance also acted as an indicator to assess the effectiveness of the village forest (Rakatama \& Pandit, 2020).

Hence, this study aimed to examine the readiness and capacity of SF organisations under the FMU framework to reduce the poverty of the community that utilises the forest directly, thus empowering and strengthening the community's capacity as forest users and beneficiaries. Plus, it improves the forest environments in terms of maintaining the forest from deforestation and other destructive activities to ensure sustainability and biodiversity.

Finally, this research provided a holistic evaluation of social forest policy achievements in Aceh Province, Indonesia, with regards to its objectives to promote economic benefits. The study also produced an institutional evaluation that contributed to further planning and practices of village forests in Aceh Province, Indonesia.

\section{MATERIAL AND METHOD}

In Indonesia, SF is the formalisation of community-based forest management that 
is regulated in government policies and administration activities. The policy on village forests refers to the employment of land use rights and ownership rights (Erbaugh, 2019), which indicates that the community has special rights to the forest area granted by the Indonesian state. The issue under study is part of the new government policy implementation on SF. SF was established under the Forest Management Unit (FMU) management, plus both SF and FMU are products of relatively new policies. These policies indicate that certain changes need to be executed throughout the process of policy implementation. Furthermore, there is an evaluation of the policy's implementation particularly in the specific context, when two policies are implemented in the same area and exercised in harmony. Therefore, it is necessary to adopt a combination of approaches, namely: (i) Theory of Organisation Readiness for Change (Weiner, 2009) and (ii) Policy Implementation Assessment (Klaus et al., 2016). Certain modifications were made in merging these two concepts and applying them from a bottom-up perspective. Each method was adjusted to and adapted to a specific situation at SF and FMU in Aceh, as outlined in the methods.

FMU is an institution that supervises forest management at a site level (Barrette et al., 2018; Saputra \& Dewata, 2019). The establishment of FMU was mandated by Law No. 41 Year 1999 with regards to forestry. Moreover, Article 12 of this particular law affirmed that forestry planning includes forest inventory, forest area gazettement, forest use planning, management area allotment, and forest plan design. Additionally, FMU was established in 2013 through Governor Regulation No. 20 Year 2013. FMU was involved in the implementation of forest management, preparation of strategic, tactical, and operational planning, management of land uses, harvesting, transformation and marketing, and control management (Beaudoin et al., 2015). Besides, the function of FMU included those related to community forest management (Jafari et al., 2018) through the village forest scheme. The village forest is the state forest managed by a village and utilised by them for the village community's welfare. Thus, the FMU plays an important role in facilitating, fostering, and overseeing forest management conducted by the village forest manager, the Village Forest Management Institution.

One of the village institution's role is to present a forest license proposal to the Indonesian Minister of Environment and Forestry to achieve the village forest objectives. Hence, in this research, the evaluation was conducted to monitor the extent to which the village forest objectives have been achieved (Maryudi et al., 2012), as shown in Table 1. Considering the difficulty in achieving these objectives without support from related institutions (Dash \& Behera, 2015), the overall assessment of the institutions' maturity level is completed using process-based mapping analysis.

The research was conducted in three village forests in Pidie District, Aceh 
Province, Indonesia, namely Gampong Lutueng, Gampong Mane, and Gampong Blang Dalam. The Pidie district is geographically located at $04.30^{\circ}-04.60^{\circ}$ North Latitude (NL) and $95.75^{\circ}-96.20^{\circ}$ East Longitude (EL), bordering the Straits of Malacca in the north, West Aceh District and Aceh Jaya in the south, Aceh Besar District in the west, and Pidie Jaya District in the east (Central Bureau Statistics, 2018). The Pidie Regency covers 23 subdistricts and consists of 94 mukim and 731 villages/gampong with a total area measuring 3,562.14 Ha. The population of Pidie district is approximately 425,974 people, with a density of 120 individual/ $\mathrm{km}^{2}$ (Central Bureau Statistics, 2018). Besides, the unemployment percentage was recorded at approximately 7.64\% (Central Bureau Statistics, 2018). The poverty level measured by income per capita is worth IDR
408,150 and equated with the consumption of 2,100 calories per capita/day (Central Bureau Statistics, 2018). Based on the income per capita, 92,350 people, or $21.43 \%$ of the Pidie population were living below the poverty line (Central Bureau Statistics, 2018).

In addition, the income or livelihood of the community was divided into 17 types of main business fields and grouped into seven major sectors, namely agriculture, forestry and fisheries, industrial trade, government administration, defence and social security, transportation and warehousing, and mining and quarrying. Based on the Indonesian Central Bureau of Statistics, agriculture, forestry, and fisheries are a part of the natural resources group, which is the largest group that contributes to the GDP with an estimated total of IDR 3,751,024.22 or $29 \%$ (Central Bureau Statistics, 2018).

Table 1

Objectives of village forest policy

\begin{tabular}{|c|c|}
\hline Objectives & Elements/Indicators \\
\hline $\begin{array}{l}\text { Economic benefits for the } \\
\text { community }\end{array}$ & $\begin{array}{l}\text { Forest products, cash money (in IDR), } \\
\text { services value }\end{array}$ \\
\hline $\begin{array}{l}\text { Benefits for forest management } \\
\text { and biodiversity conservation }\end{array}$ & $\begin{array}{l}\text { Forest patrol and monitoring, financial support for } \\
\text { wildlife mitigation, forest plant cultivation, wildlife } \\
\text { conflict mitigation. These activities to ensure forest } \\
\text { quality is protected. }\end{array}$ \\
\hline $\begin{array}{l}\text { Social benefits for community } \\
\text { strengthening, including } \\
\text { community involvement and } \\
\text { participation }\end{array}$ & $\begin{array}{l}\text { Access to (i) information on SF, access to decision- } \\
\text { makers, (ii) SF financing through village fund, (iii) } \\
\text { capacity building through village fund and other } \\
\text { stakeholders, (iv) decision making in terms of } \\
\text { opportunities to give opinions in village meetings. }\end{array}$ \\
\hline
\end{tabular}




\section{Data Collection}

The selection of village forests and the respondents was carried out using purposive sampling. The chosen sites were village forests in Aceh which were granted five years license, namely Gampong Lutueng, Gampong Mane, and Gampong Blang Dalam village forests which are part of Aceh Province FMU 1 as illustrated in Figure 1.

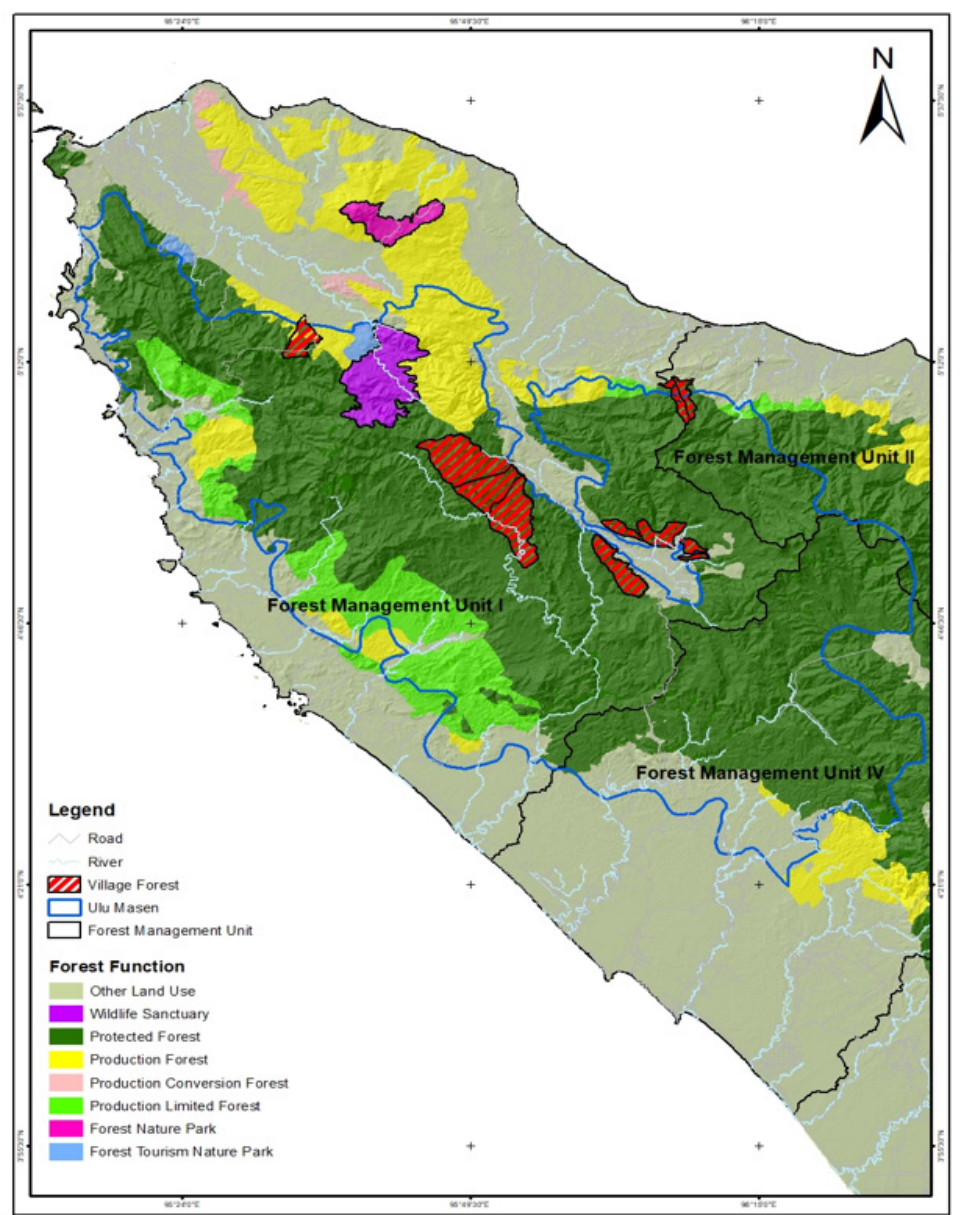

Figure 1. Research sites in FMU 1

The Gampong Lutueng forest village covers a protected forest of 2,271 ha. It is a part of the Krueng Teunom and Krueng Geumeu watershed ecosystems. The forest management of Gampong Luteung consists of cultivation activities such as seedling, planting, and selling the seeds within 140 ha. In this area, the community is also cultivating non-timber products such as dragon blood or traditionally known as 
jernang, rattan, bamboo, coffee, cocoa, fruit trees, natural honey, sugar palm, medicinal plants, and fishery products.

Secondly, the Gampong Mane village forest which is geographically located at $04^{\circ} 49^{\prime} 1.150 "$ " $04^{\circ} 56^{\prime} 37.676$ " NL and $96^{\circ} 0$ ' 13.077" $-96^{\circ} 5$ ' 11.180" EL. This village forest is expected to benefit up to 1,200 households. The forest is divided into two blocks, which comprises of protection blocks covering 4,595 ha $(97.88 \%)$ and rehabilitation blocks of 97.33 ha $(2.12 \%)$. The protection blocks are determined using variables such as high forest cover environments, water supply, flooding and erosion prevention functions, and soil fertility preservation. The rehabilitation block land, on the other hand, is mostly dry with shrubs.

Thirdly, Gampong Blang Dalam is geographically located at $4^{\circ} 52^{\prime} 32.605^{\prime \prime}-4^{\circ}$ 54' 55.160" NL and 96 7' 47.513" - 96 $16^{\circ}$ ' 37.026" EL. The LPHD of Gampong Blang Dalam was granted a forest management license for a work area of 1,048 hectares proposed by 390 households. The forest area is positioned in the Krueng Teunom watershed ecosystem which includes two sub-watersheds, namely Krueng Geumue and Krueng Inong. The work area of Blang Dalam Gampong village forest is divided into three blocks, namely the protected blocks covering an area of 515.45 ha (49.18\%), the core blocks comprising of 490.73 ha $(46.82 \%)$, and rehabilitation blocks of 41.85 ha $(3.99 \%)$. The data collected in this research is subjected to two procedures as stated below:
1. the proving of input and output from documentary sources that have been validated by authorized officials: FMU and Village Institution;

2. interview and group discussion with village institutions and FMU Regional I members. The topics include economic benefits, diversification, and innovation aimed at poverty reduction, forest management and biodiversity protection for the improvement of forest quality, and social benefits, including community involvement and participation to improve the community participation in forest management (planning, implementation, and supervision activities).

\section{Objective-Based Evaluation for Village Forest Program}

The main objective of the evaluation was to determine the accomplishments of the village forest program by assessing the target set achieved by the SF policies. The evaluation employed an approach developed by (Maryudi et al., 2012). This approach was used because it had gone through a "wrap up" process, synthesis involved a more complex to a set of simpler criteria, and had indicators focusing on the objectives of SF policy. Maryudi's approach assesses impacts that rely on the criteria and goal-based indicators consisting of poverty reduction, unemployment alleviation, and sustainable forest management (Maryudi et al., 2012). 
Each assessment indicator has its own focus. In reducing poverty indicator that must be measured are how forest products can be utilized, how much income is derived from the use of forest products, and how the community provides services to preserve the forest for example monitoring and working together with institutions in charge such as FMUs, village headman, and police department. The second indicator is unemployment alleviation where community members can access forest information, decision, and forest land and resources. This element is related to how the government can prevent tenurial claims. While the third element, sustainable forest management by improving forest conditions such as planting native species of old-growth forest that someday invaluable. Also, these third indicator is regarding biodiversity.

In the previous research (Furness et al., 2015), Maryudi's assessment was used to evaluate the objective of forest management policy implementation in British Columbia in Canada. The aim of this research was to generate information about the strengths and weaknesses of related institutions. Also, the result indicated that the objectives of forest management policies were successfully achieved. Even though it did not align with to degree of economic benefits, the participation from the community was high.

\section{Process-based Mapping Analysis Evaluation Approach}

The process of implementing SF policies in the village forest scheme requires a cooperative role among stakeholders. FMU which acts as the forest area manager is a state representative in terms of providing public needs for the forests. This approach is also called interaction fields and space approach with a method so-called as the process-based mapping analysis (National Academies of Sciences, Engineering, and Medicine, 2011). There are three aspects of process-based mapping (i) Time-momentum matching, (ii) Management effectiveness matching, and (iii) Institutional maturity matching. Table 2 shows the descriptions of each aspect.

Table 2

Aspects of institutional maturity and descriptions

\begin{tabular}{ll}
\hline Aspects & Descriptions \\
\hline Time momentum & It is measured by aligning the institutional development process \\
Matching & and interaction between village forest management institutions \\
& and FMU. The indicator of measurement contains a period of \\
& formation, institutionalization, pre-condition operational, and \\
& advancement time. Each indicator has elements, the measurement \\
& result is presented on as 1 to 3 scale. The final result is presented \\
& as an index generated by adding up elements scores.
\end{tabular}


Table 2 (Continued)

\begin{tabular}{ll}
\hline Aspects & Descriptions \\
\hline Management effectiveness & $\begin{array}{l}\text { The measurement contains indicator groups such as objectives, } \\
\text { institution instruments, programmes, and funding. Each indicator } \\
\text { is also having an index value generated by the measurement of } \\
\text { indicators' element. The final result of this measurement is also } \\
\text { presented as 1-3 scale. }\end{array}$ \\
& $\begin{array}{l}\text { This aspect describes the level of alignment among related } \\
\text { institutions which in this case institutions are village forest } \\
\text { management institutions and FMU. This measurement includes } \\
\text { matching }\end{array}$ \\
& $\begin{array}{l}\text { all operational elements such as the fulfilment of legal aspects, } \\
\text { organisational structure, job descriptions, organisational } \\
\text { commitment, facilities, human resource and development, } \\
\text { funding, short-term and long-term management planning, } \\
\text { business planning, and partnership. The final result of these } \\
\text { aspects is also presented as scale from 1 to 3. }\end{array}$ \\
\hline
\end{tabular}

While focusing on the process-based mapping analysing, this study investigates the development, status of implementation, and operationalisation of FMU and village forest within 5 years period. Besides, the maturity of the village institution as the manager of the village forest and FMU as the manager of forest areas were also assessed using this approach since the analysis is based on the mapping of inputs and outputs. The mapping of inputs and outputs is based on the process stages that are described in the form of graphs where $\mathrm{x}$ is the growth and $\mathrm{y}$ is the period (time) of the occurred process.

\section{RESULTS AND DISCUSSION}

The State of Village Forest Policy Implementation: Objective-Based Evaluation

The indicators of measurement are following the objectives of village forest management by the community that is to reduce poverty, to promote forest governance and social framework, and to strengthen community participation. Each indicator group consists of several elements which are referred to as quality elements. By dividing the total value of the indicator by the number of quality elements, the accumulated value of the indicator is known. The number of quality elements is equal to the number of benchmarks being used. Figure 2 depicts the outcome of the objective-based evaluation.

Based on Figure 2, the performance of the village forest continuously improved from 2013 to 2018. Also, the forest governance (maintaining and protecting forest) progressed better than that of increasing the economic value and benefits enjoyed by the village institution. This result can be objectively interpreted as efforts 


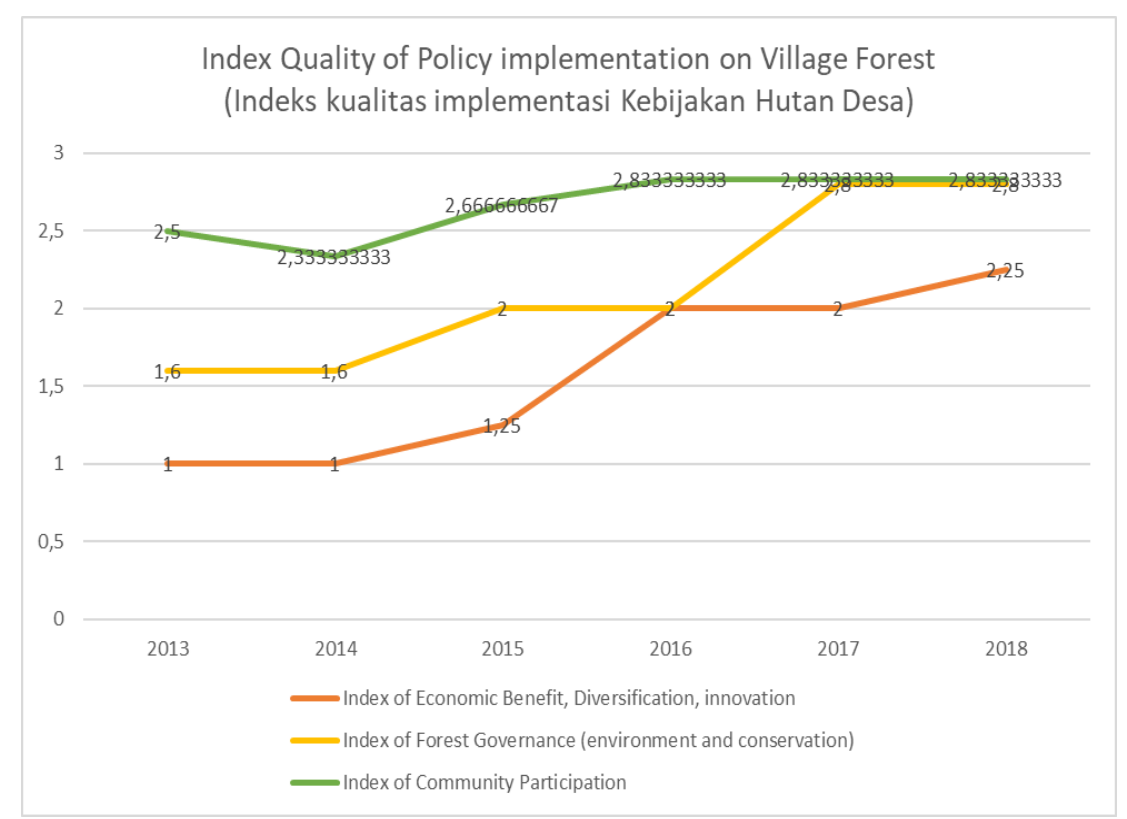

Figure 2. Index quality of policy implementation on Village Forest

in performing physical activities such as forest maintenance and patrolling are much simpler than the efforts put into improving the economic and institutional values.

Economic Benefit, Business Type, and Innovation. One of the objectives of the social forest was to provide access for the community to use forest products to support their livelihood which was not limited to forest products but also the availability of ecosystem services. Forest products and ecosystem services are expected to contribute to the community's income. The community utilising the forest products such as manau rattan, slimit rattan, and dragon blood were recruited as the respondents for this study. On the other hand, the income made from the business managed by the community group could be divided into three businesses of community groups with 10 members each. Of the total revenue, approximately $12 \%$ to $44 \%$ was contributed to village institutions while the income earned by group members ranged from $56 \%-88 \%$.

Based on Figure 2, the index value of the implementation of village forest management policies in terms of improving the economy through activities aimed at increasing people's economic benefits in 2013 to 2014 was recorded at 1 point, which then increased to 2 points in 2015 and maintained at it in 2016 and 2017. The index value then continued to increase up to 2.25 in 2018 . The slow performance of the index value between 2013 and 2014 could most likely be due to the initiation phase of the 
village forest which involved the proposal submission and acceptance procedure. During the initial stages, the organisational structure was also informal as it has not been approved by the government. Besides, there was no regular funding to support economic activities at this point. Hence, the situation led to the absence of businesses and innovations. Fortunately, once the village forest proposal was approved in 2015, the index value experienced an increase. This increase was a result of the business funding assistance from non-governmental organisations for community groups in each of the village forest management institutions. Moreover, from 2016 to 2017, governmental funding support was also obtained which contributed to the enhancement of village forest achievement. This funding scheme was regulated by the Minister of Villages, Underdeveloped Regions, and Transmigration concerning
Priority Use of Village Funds regulation. Business activities were then carried out under a profit-sharing mechanism and/or also used to fund the village institution itself. Once the village forest was formalised, funded, and was fully monitored by the government, the index value continued to rise. Hence, in 2018, the index value was estimated at 2.25 points.

On the other hand, the community members had also begun to create innovative products particularly utilising non-timber forest products such as jernang, silimit rattan, and manau rattan. Through FMU Region 1 and Ministry of Environment and Forestry, the community skills were improved to produce valuable products from non-timber products by facilitating group learning and production tools. Figure 3 indicates the income earned from nontimber product utilisation in 2018.

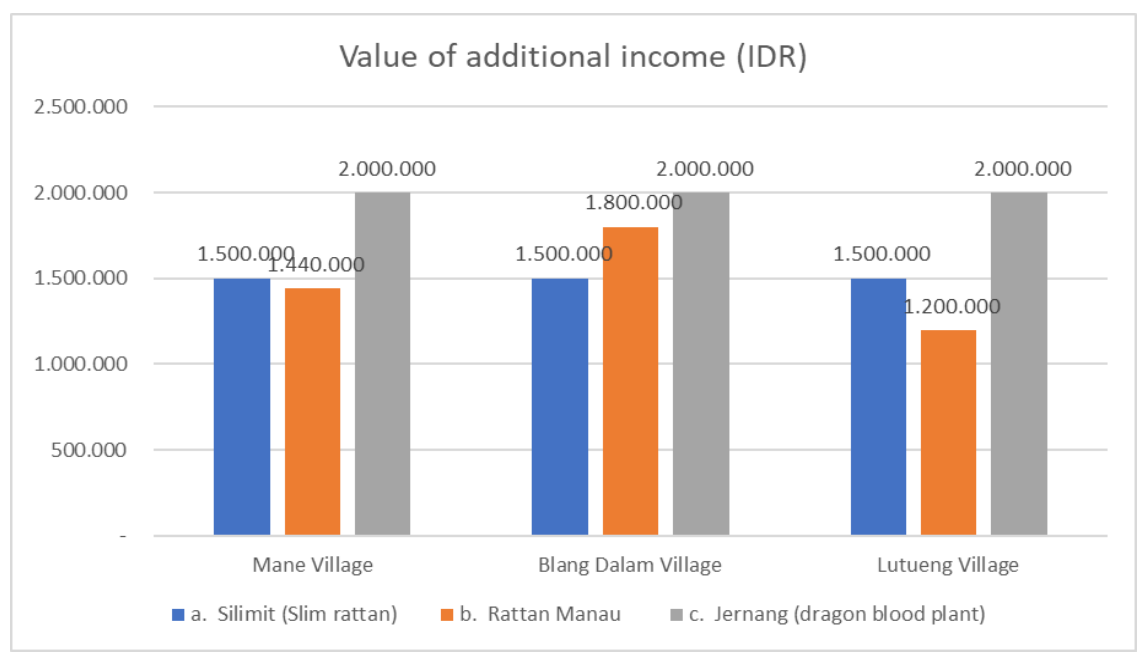

Figure 3. The additional income from jernang, silimit, and manau rattan in 2018 
During the time of regulation of the funding scheme by the ministry, increased funds were also obtained from business such the cattle and buffalo fattening. The cattle fattening business income recorded approximately IDR 4,5000,000 per year for every household while sharing income with the village forest institution was recorded at IDR 960,000 to IDR $11,500,000$ per year.

Policy to Protect and Conserve the Forest. The implementation of SF policies including the village forest scheme is also targeted to sustain forest resources. In this study, the goal was set to assess the reach of the forest protection and conservation implemented through forest management by the community. To measure this objective, the indicators of forest protection and conservation were constructed through the execution of the conservation-based initiatives related to forest protection including forest patrol and monitoring, prevention of deforestation, wildlife conflict mitigation, and other activities that support the use of environmental-friendly forest products.

Based on Figure 1, the index of forest governance by village forests in 2013 and 2014 was recorded at 1.6 points, since 2013 to 2014 was the period where the village forest was still under initiation and proposal process. During these starting years, the conservation agenda was not yet in place as was no activity related to the use of environmentally friendly forest products. However, beginning 2015 the index value grew by 0.4 points to 2 . The slight growth was contributed by the good interest of the community in preparation for the village forest management plans while waiting for the permit issuance upon submitting the license proposal to the government. In 2015 and 2016, the initiatives to protect forests through patrol and monitoring activities were introduced. Simultaneously, deforestation prevention, wildlife conflict mitigation, and other activities supporting the use of environmental-friendly forest products were also included in the village forest planning documents. From 2016 until 2017, the community had also initiated the inclusion of forest management and wildlife mitigation into their village development plan, so that the wildlife mitigation activities could be supported by the village funds. The community proposal for wildlife conflict mitigation to be financed by the village funds was based on the Regulation of Village Minister concerning priority use of village funds.

From 2017 to 2018, the index value increased and maintained at 2.8. One of the factors that led to growth during this period is the financial support from the government. Funding of around IDR $69,000,000$ was received by the village institution and was distributed to Gampong Lutueng's, Blang Dalam's, and Gampong Mane's to assist forest governance. The other supporting factor was a conservation agenda that was accommodated in the village forest management plan and village mid-term development plan. Moreover, forest patrol and monitoring were also included in the planning agenda. The patrol 
and monitoring teams were established by adat mukim institution in Lutueng settlement to eliminate wildlife conflicts.

Policy Effectiveness to Strengthen Community Capacity. One of the SF policy involved the capacity strengthening of the community to manage the forests to ensure the forest management and utilisation of forest products can be carried out in accordance with the principles of sustainable forest management. The aspect of social benefits as a partial under forest management was evaluated based on the community participation consisting of the participation rates in village institutions, number of community members involved in village meetings, number of people involved in business units, the participation rate of the community involved in the management of village institutions, number of members of village institutions involved in the drafting of the village development plan, and the participation of women in the management of village institutions.

The study revealed that the community actively participated in the socializing and discussing forest management related issues where decisions were made after much deliberation. During village discussion sessions, nearly $60 \%$ of the community members invited to the village discussions were present and contributed their inputs. The index value of public participation which was 2.5 in 2013 increased to 2.67 in 2014 and 2015. The index growth is promoted by the increased participation during the process of license proposal submission and the strengthened community interest to be involved as advisors in the leadership structure of the village institutions.

Further, in 2017 and 2018, community participation increased to 2.83 . The increase was triggered by community participation along with the integration of village forest management requirements into the villages' development plan consultative process. One of the factors that led to the participation growth in the planning process was the policy foundation, where the ministerial regulation of village development stipulated that the village forests was one of the programs in priority to use village funds. The other factor was the demand to increase the capacity of business group members and mitigate wildlife conflicts.

Based on the results, the index indicated that the forest-related main capital currently owned by the community was considered as the main social benefit compared to the other objectives of SF policies. The index of social benefits since the initiation stage in 2013 up to the operational phase in 2019 was maintained between 2.5 to 2.83 . It indicates that not only a strong capital but also the need and interest to make the forest as part of objects which use and protection must be planned.

The study also demonstrated that the economic benefits showed improvement. The index value of economic benefits in 2013 was 1 , which then increased to 2.25 in 2018. On the other hand, the median index value was recorded by the benefits of forest governance and protection, where the index 
value of this particular benefit increased to 2.8. In 2018 from 1.6 in 2013.

Based on all the index values, SF policies were found to be supported by the priority use of village funds. The SF and village funds are the two main factors that helped to escalate community participation in sustainable forest management. Table 3 summarises an overview of the village funds allocated through community proposal submissions and approval in the case study area between 2017-2018.

Besides, providing economic sources to the community, there is forest stand quality improvement which also aligns with ecological sustainability. The satellite images analysis employed annually from 2014 up to 2018 indicated that forest stand had improved significantly. In terms of forest cover, there was an average increase of 564 hectares annually at 3 villages (totally occupied 17,632 hectares of forest land). This is important evidence that village forest management has the capability in maintaining the forest stand, aside from benefiting out of the licensed areas as illustrated in Figure 4.

Table 3

The budget allocation for forest village from village fund, 2017-2018

\begin{tabular}{|c|c|c|c|c|c|c|}
\hline \multirow[t]{2}{*}{ No } & \multirow[t]{2}{*}{ Village } & \multicolumn{2}{|c|}{ Amount of Village Fund (IDR) } & \multicolumn{3}{|c|}{$\begin{array}{l}\text { Amount of Allocation Fund for } \\
\text { Village Forest Management } \\
\text { Institution (IDR) }\end{array}$} \\
\hline & & 2017 & 2018 & 2017 & 2018 & 2019 \\
\hline 1 & $\begin{array}{l}\text { Blang } \\
\text { Dalam }\end{array}$ & 788.612 .181 & 1.108 .000 .000 & & 20.000 .000 & - \\
\hline 2 & Lutueng & 973.985 .002 & 977.000 .000 & 10.000 .000 & 29.000 .000 & - \\
\hline 3 & Mane & 1.083 .365 .795 & 2.000 .000 .000 & & 20.000 .000 & - \\
\hline
\end{tabular}

\begin{tabular}{|c|c|c|c|c|c|}
\hline \multirow[t]{2}{*}{ No } & \multirow[t]{2}{*}{ Village } & \multicolumn{3}{|c|}{$\begin{array}{l}\text { Percentage of Village Fund Allocation for } \\
\text { Village Forest Management Institution } \\
(\%)\end{array}$} & \multirow[t]{2}{*}{$\begin{array}{l}\text { Amount of budget has } \\
\text { been allocated for the } \\
\text { Village Forest in } 2 \text { years }\end{array}$} \\
\hline & & 2017 & 2018 & 2019 & \\
\hline 1 & Blang Dalam & & 1,81 & - & 20.000 .000 \\
\hline 2 & Lutueng & 1,03 & 2,97 & - & 39.000 .000 \\
\hline 3 & Mane & & 1,00 & - & 20.000 .000 \\
\hline
\end{tabular}




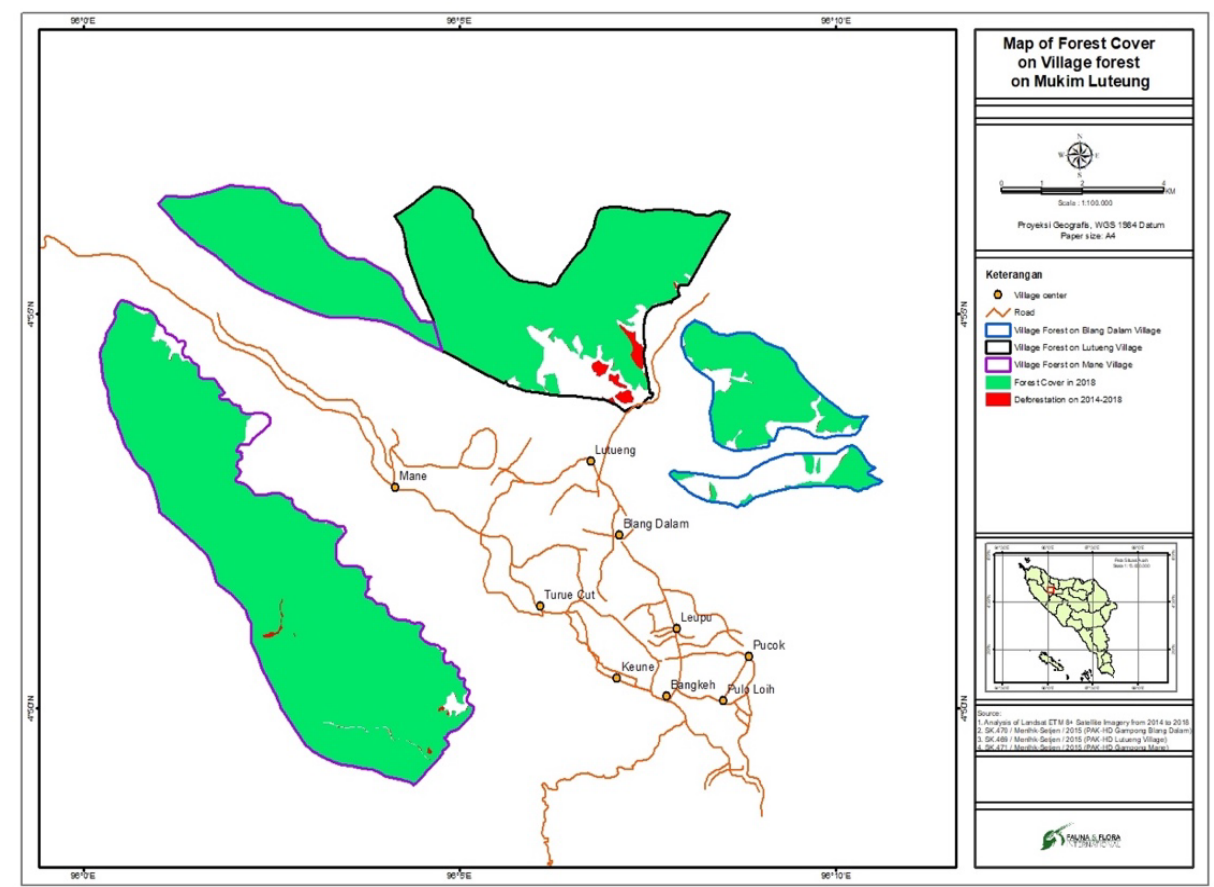

Figure 4. Additional forest cover on 3 village forests (based on ETM 8+ satellite images)

\section{Results and Discussion Generated from Process-based Mapping Analysis}

In addition to the objective-based evaluation, process-based mapping analysis was employed to determine the factors contributing to the quality of the process in governing and managing the village forest. In other words, learning power as one of the components in knowledge management may be well outlined in this approach. This approach is performed when two or more institutions experience development phases at the same time. The process consists of several stages in the aspect of the operationalisation of institutions. The matching process that was executed, engaged FMU and Village Institutions as forest managers. Both institutions grew relatively in the same period, 2013-2018. During this period, both organisations performed their respective functions and tasks accordingly. Hence, it is also part of the process mapping approach to examine the effectiveness of joint performance on the ground. In short, the process-based mapping approach delivers three thematic matchings, namely (National Academies of Sciences, Engineering, and Medicine, 2011):

- Time-momentum matching

- Management effectiveness matching

- Institutional maturity matching

Time-Momentum Matching. There are two consecutive stages of institution development, namely the preparatory 
or instalment stage, and the operation stage (Strand, 2001). The initiation, establishment, institutionalisation, and pre-conditions processes are referred to as the maturity level of an organisation during the instalment stage. This stage reflects on the institutional situation whether the operational and management systems are being accommodated on a preparatory or informal basis. Hence, the operational process is defined to be at rationalised level and development stages at the alignment level.

This study focused on the FMU and village forest programs from 2013 to 2018. Each of the organisation experienced their journey of development but were observed to interact with each other as depicted in Figure 5.

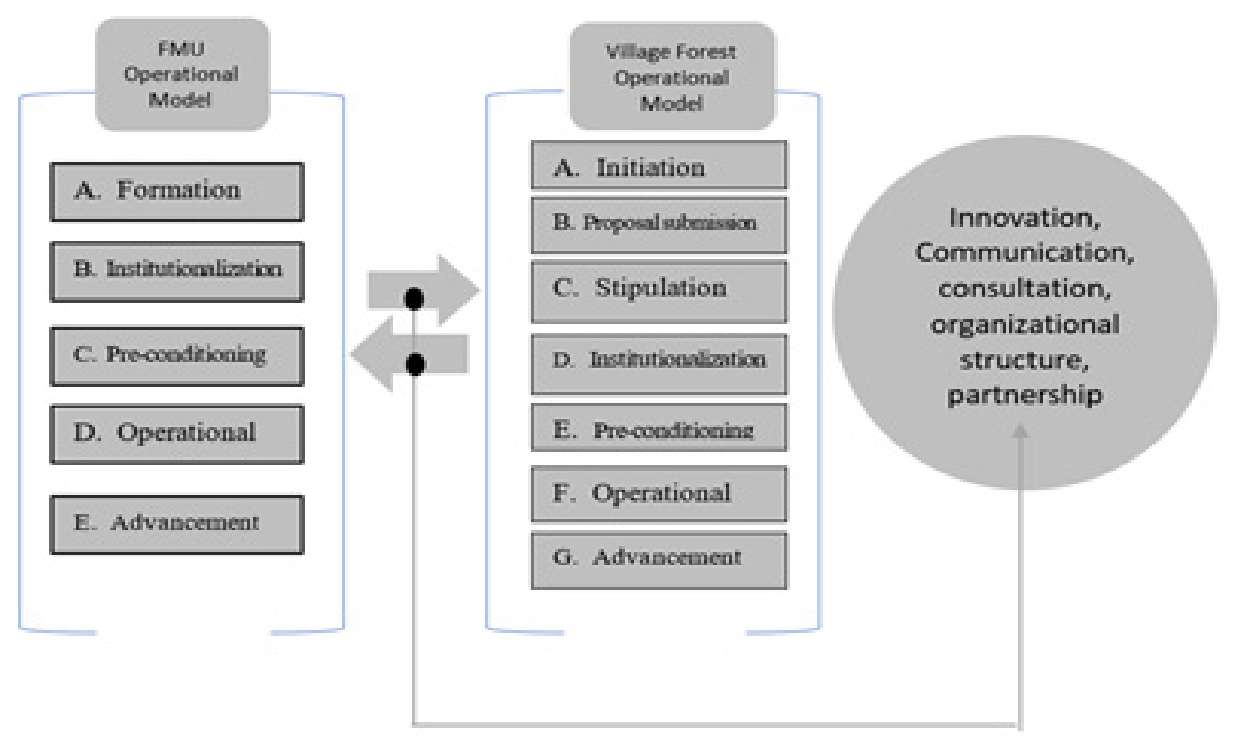

Figure 5. Institutional development and interaction between FMU and Village Forest

The matching dynamic between the stages of development of FMU and the village forest is diagrammatically expressed in Figure 6. Some of the observations that can be taken from this thematic map include:

FMU should interact with the village forest even during the establishment phase when the new organisation was set up. This interaction will ensure both FMU and village forest to exchange ideas and opinions from each other's institutional development. The pace of development of both institutions may not be the same or even parallel (Balkin \& Gomez-mejia, 1990). It may be caused by some difficulties encountered by the village forest prior to the establishment of FMU. Some bureaucratic barriers (authority, rights, and scheme of 
distribution of benefits) will have to be addressed before smooth interactions can take place.

Village forest advanced in terms of development, while FMU was still trying to perform better in the initial operation. More effort is needed by the FMU management to cope with this unbalanced stage of institutional development.

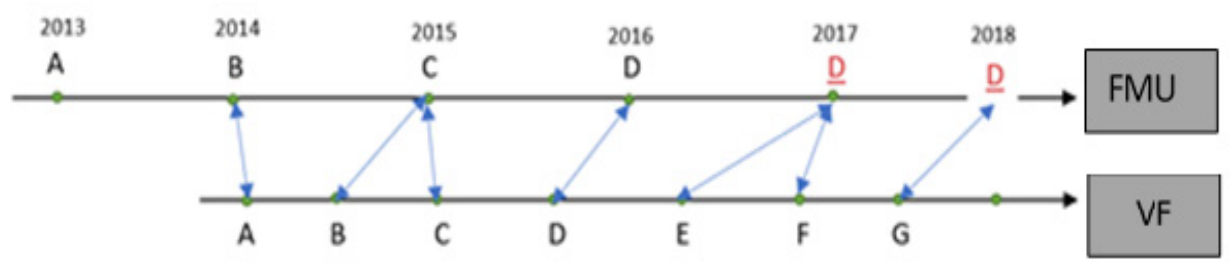

Figure 6. Time-momentum matching between FMU and Village Forest

Management Effectiveness Matching. Management effectiveness matching aims to observe the area of commonness on the management between FMU and Village Forest institutions. Observations were made based on the semantic expression in the relevant management documents (Legal documents, Corporate profiles, Management Plan, and confirmation and articulation during interviews). The composite index ranged from 1 to 3 was applied as an aggregated valuation of the common patterns.

This matching type consists of four indicators, namely (1) commonness of the long-term management objectives, (2) similarity of program areas, (3) management instrumentation, and (4) availability of funding to support potential management partnership. Figure 7 represents the analysis result.
Figure 7 indicates that both FMU and Village Forest run similar practices and program in their institutional objectives. Therefore, the collaboration between the two institutions became decent. On the other hand, both the institutions still have to prepare the institutional instruments such as management standards, coordination mechanism, and competencies of the staff to follow.

Institutional Maturity Matching. The institutional maturity matching was observed between 2013 to 2018 in this study. The analysis made use of three different stages of institutional maturity (National Academies of Sciences, Engineering, and Medicine, 2011).

Level 1: ad-hoc institution, which is characterised by mixed, hero driven leadership, fragmented organisation and 


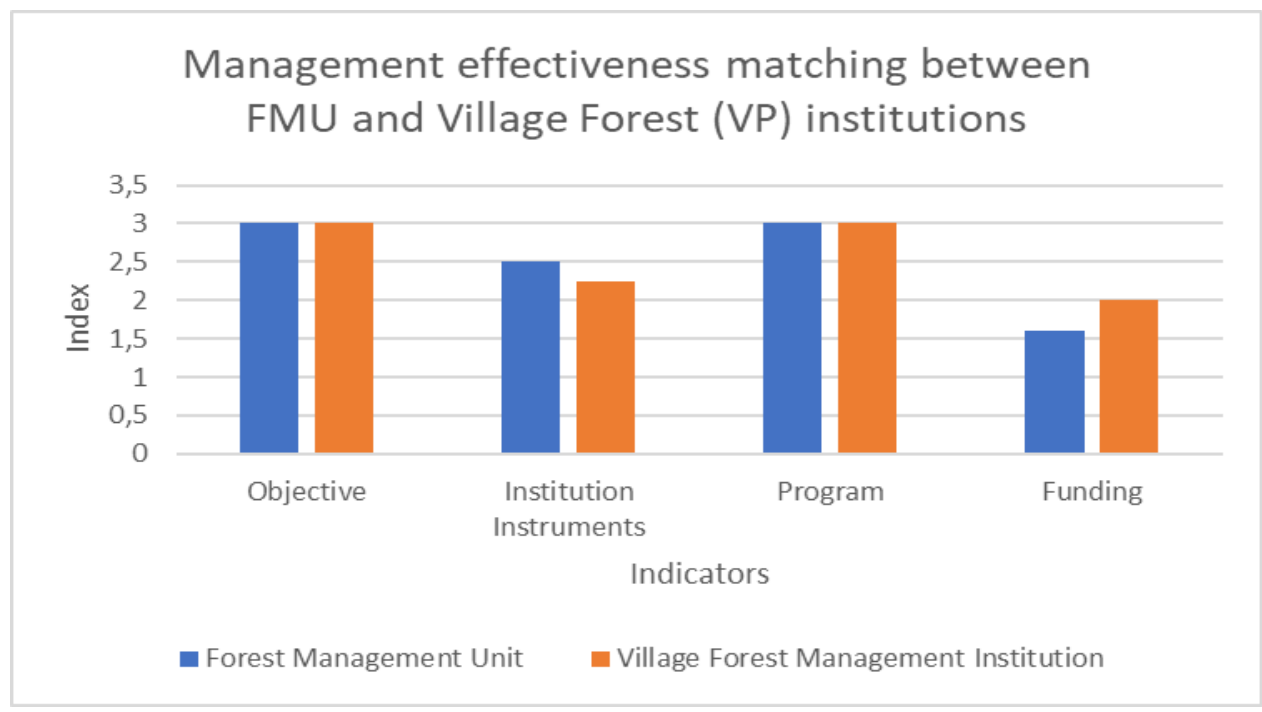

Figure 7. Management effectiveness matching between FMU and VP institutions

staffing, project-like resource allocation, and informal partnership

Level 2: rationalised institution, which is characterised by championed leadership that is internalised across disciplines, aligned organisation, competent staff, resource allocation based on program, and formal, aligned partnership

Level 3: leadership oriented towards commitment, integrated organisation and staffing, sustainable funding and budgeting, and consolidated partnership

The index for institutional maturity was operated against indicators that have been set up for forest management performance, consisting of social, ecological, economic, and the institution of management operation. The assessment of the indicators was performed using an ordinal scale.

Based on the outcome, the institutional maturity of Village Forests management was relatively above that of FMUs'. This phenomenon can be factually explained as follows:

The management of village forest was and still is intensively facilitated, guided, and supervised by NGO activists (Fauna and Flora International).

The management of FMU is formally reviewed by the Provincial Forestry Office. From the beginning (2013) up to 2016, FMU grew consistently and the index for maturity increased from 1.3 to 2.0 (from the scale of 0 to 5.0). However, after 2016, the rate of maturity seemed to slow down and was over-taken by the maturity of Village Forests. In fact, the performance of FMU was affected by changes in leadership at FMU and the Provincial Forestry Office.

It is believed that the institutional maturity of forestry institutions is best developed by intensive and consistent 
coaching, advising, and supervising activities. Therefore, the maturity index of an institution may start from a very low level (around 1 on the scale of 1 to 3 ) during the initiation and work its way to full maturity after several years. However, the respective organisation may still encounter high risk while developing towards mature and stable management (as classified with maturity index with level 3) as seen in Figure 8.

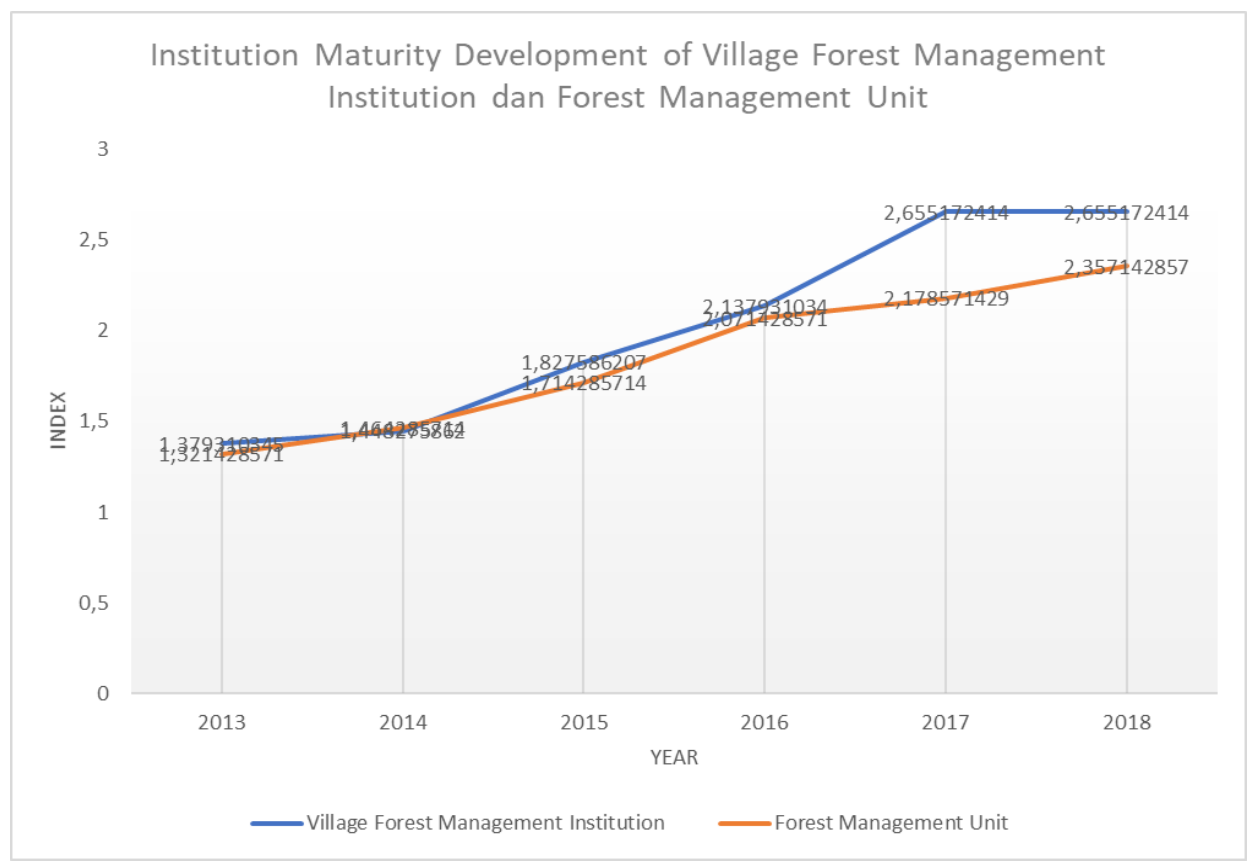

Figure 8. Institution maturity development of Village Forest Management Institution and FMU

\section{CONCLUSIONS}

To conclude, this study revealed that the Village Forests community, FMU, national governments, and village institutions must work together to support SF. Their similar vision and mission towards $\mathrm{SF}$ contribute to a better institutional maturity level. In regards to the success of the village forest, the village forest policy has to be supported by other policies. This study demonstrated that the integration between the village forest policy with the priority funding policy contributed to the success of the village forest implementation. These policies aid in developing and implementing forest protection steps such as forest patrol, monitoring, and wild-animal conflict mitigation. Based on the economics perspective, the integration of these policies reinforces community members to manage non-timber products such as rattan and jernang to improve their quality of life. 
This study also revealed that the maturity level of FMU and village institutions were influenced by other policies. The local policy number 23 year 2014 positively influenced the maturity level of FMU, while the maturity level of the village institution was influenced by village funding policy.

\section{ACKNOWLEDGEMENT}

We gratefully acknowledge the participation of the Village Forest community at the study site area, Provincial Board of Environmental and Forestry of Aceh Province, Forest Management Unit I of Aceh Province, and Fauna \& Flora International - Indonesia for data sharing and technical support in this study.

\section{REFERENCES}

Aju, I., Resosudarmo, P., Tacconi, L., Sloan, S., Almuhayat, F., Hamdani, U., ... \& Zahrul, M. (2019). Indonesia's land reform: Implications for local livelihoods and climate change. Forest Policy and Economics, 108, 101903. https://doi. org/10.1016/j.forpol.2019.04.007

Balkin, D. B., \& Gomez-mejia, L. R. (1990). Matching compensation and organizational strategies. Strategic Management, 11, 153-169. https://doi.org/10.1002/smj.4250110207

Barrette, J., Paré, D., Manka, F., Guindon, L., Bernier, P., \& Titus, B. (2018). Forecasting the spatial distribution of logging residues across the Canadian managed forest. Canadian Journal of Forest Research, 48(12), 1470-1481.

Beaudoin, J., Bouthillier, L., \& Chiasson, G. (2015). Land use policy growing deep roots: Increasing aboriginal authority in contemporary forest governance arrangements. Land Use
Policy, 49, 287-295. https://doi.org/10.1016/j. landusepol.2015.08.004

Bong, I. W., Moeliono, M., Wong, G. Y., \& Brockhaus, M. (2019). What is success? Gaps and trade-offs in assessing the performance of traditional social forestry systems in Indonesia. Forest and Society, 3(1), 1-21. https://doi.org/10.24259/fs.v3i1.5184

Central Bureau Statistics. (2018). Master file Wilayah Provinsi Aceh 2018. Aceh Province, Indonesia: Author.

Dash, M., \& Behera, B. (2015). Local institutions, collective action and forest conservation: The case of Similipal Tiger Reserve in India. Journal of Forest Economics, 21(4), 167-184. https://doi. org/10.1016/j.jfe.2015.09.001

Erbaugh, J. T. (2019). Forest policy and economics responsibilization and social forestry in Indonesia. Forest Policy and Economics, 109, 102019. https://doi.org/10.1016/j.forpol.2019.102019

Fisher, M. R., Dhiaulhaq, A., \& Sahide, M. A. K. (2019). The politics, economies, and ecologies of Indonesia ‘s third generation of social forestry: An introduction to the special section. Forest and Society, 3(1), 152-170. doi:10.24259/ fs.v3i1.6348

Fisher, M. R., Moeliono, M., Mulyana, A., Yuliani, E. L., Adriadi, A., Kamaluddin, ... \& Sahide, M. A. K. (2018). Assessing the new social forestry project in Indonesia: Recognition, livelihood and conservation? International Forestry Review, 20(3), 346-361. https://doi. org/10.1505/146554818824063014

Furness, E., Harshaw, H., \& Nelson, H. (2015). Community forestry in British Columbia: Policy progression and public participation. Forest Policy and Economics, 58, 85-91. https://doi. org/10.1016/j.forpol.2014.12.005

Gauld, R. (2000). Maintaining centralized control in community-based forestry: Policy construction 
in the Philippines. Development and Change, 31(1), 229-254. https://doi.org/10.1111/14677660.00153

Hutauruk, T. R., Lahjie, A. M., \& Simarangkir, B. D. A. S. (2018). The prospect of the utilization of non-timber forest products from Setulang Village forest based on local knowledge of the Uma Longh community in Malinau, North Kalimantan, Indonesia. Biodiversitas Journal of Biological Diversity, 19(2), 421-430. https://doi. org/10.13057/biodiv/d190209

Jafari, A., Sadeghi, H., Azadi, H., Gebrehiwot, K., Aghamir, F., \& Passel, S. V. (2018). Forest policy and economics assessing the sustainability of community forest management: A case study from Iran. Forest Policy and Economics, 96, 1-8. https://doi.org/10.1016/j.forpol.2018.08.001

Khalyani, J. H., Namiranian, M., Vaezin, S. H., \& Feghhi, J. (2014). Development and evaluation of local communities incentive programs for improving the traditional forest management: A case study of Northern Zagros forests, Iran. Journal of Forestry Research, 25(1), 205-210. https://doi.org/10.1007/s11676-013-0399-9

Klaus, J., Peter, K., Mangalagiu, D., \& RodríguezLabajos, B. (2016). Approach to assessment of policy effectiveness. Cambridge, England: Cambridge University Press.

Maryudi, A., Devkota, R. R., Schusser, C., Yufanyi, C., Salla, M., Aurenhammer, H., ... \& Krott, M. (2012). Back to basics: Considerations in evaluating the outcomes of community forestry. Forest Policy and Economics, 14(1), 1-5. https:// doi.org/10.1016/j.forpol.2011.07.017

Ministry of Forest and Soil Conservation. (2012). Persistence and change: Review of 30 years of community forestry in Nepal. Lalitpur, Nepal: Multi Stakeholder Forestry Programme (MSFP).

Moeliono, M., Thuy, P. T., Bong, I. W., \& Wong, G. Y. (2017). Social forestry - Why and for whom ? A comparison of policies in Vietnam and Indonesia.
Forest and Society, 1(2), 1-20. doi:10.24259/ fs.v1i2.2484

National Academies of Sciences, Engineering, and Medicine. (2011). Guide to improving capability for systems operations and management. Washington, USA: The National Academies Press. https://doi.org/10.17226/14513.

Rakatama, A., \& Pandit, R. (2020). Forest policy and economics reviewing social forestry schemes in Indonesia: Opportunities and challenges. Forest Policy and Economics, 111(1), 102052. https:// doi.org/10.1016/j.forpol.2019.102052

Resosudarmo, I. A. P., Tacconi, L., Sloan, S., Hamdani, F. A. U., Subarudi, Alviya, I., \& Muttaqin, M. Z. (2019). Indonesia's land reform: Implications for local livelihoods and climate change. Forest policy and economics, 108, 101903. https://doi. org/10.1016/j.forpol.2019.04.007

Santika, T., Wilson, K. A., Budiharta, S., Kusworo, A., Meijaard, E., Law, E. A., ... \& Struebig, M. J. (2019). Heterogeneous impacts of community forestry on forest conservation and poverty alleviation: Evidence from Indonesia. People and Nature, 1(2), 204-219. https://doi.org/10.1002/ pan3.25

Saputra, J., \& Dewata, I. (2019). Tenurial conflict between parties in the technical implementation unit of the Banjar Regency Forest Management Unit in the Province of South Kalimantan. IOP Conference Series: Earth and Environmental Science, 314, 12027. https://doi. org/10.1088/1755-1315/314/1/012027

Strand, P. S. (2001). Momentum, matching, and meaning: Toward a fuller exploitation of operant principles. The Behavior Analyst Today, 2(3), 170-175. https://doi.org/10.1037/h0099929

Tacconi, L., \& Muttaqin, M. Z. (2019). Reducing emissions from land use change in Indonesia: An overview. Forest Policy and Economics, 108, 101979. https://doi.org/10.1016/j. forpol.2019.101979 
Tajuddin, T., Supratman, S., Salman, D., \& Yusran, Y. (2019). Bridging social forestry and forest management units: Juxtaposing policy imaginaries with implementation practices in a case from Sulawesi. Forest and Society, 3(1), 97-113. https://doi.org/10.24259/fs.v3i1.6049

Weiner, B. J. (2020). A theory of organizational readiness for change. In P. Nielsen \& S. A. Birken (Eds.), Handbook on implementation science. Cheltenham, England: Edward Elgar Publishing. https://doi.org/10.4337/9781788975995.00015
Yemiru, T., Roos, A., Campbell, B. M., \& Bohlin, F. (2010). Forest incomes and poverty alleviation under participatory forest management in the Bale Highlands, Southern Ethiopia. International Forestry Review, 12(1), 66-77. https://doi. org/10.1505/ifor.12.1.66 